\title{
Purification and Characterization of Astrocyte Precursor Cells in the Developing Rat Optic Nerve
}

\author{
Huaiyu Mi and Ben A. Barres \\ Stanford University School of Medicine, Department of Neurobiology, Fairchild Science Building, Stanford, California \\ 94305-5125
}

\begin{abstract}
The signaling interactions that control oligodendrocyte generation from their precursor cells have been studied intensively. Much less is known about how astrocyte generation is normally controlled. Here we report the purification and characterization of astrocyte precursor cells (APCs) from the developing rat optic nerve. APCs are antigenically distinct from astrocytes. Both cell types are $\mathrm{Pax} 2^{+}$and vimentin ${ }^{+}$, whereas astrocytes are $\mathrm{GFAP}^{+}$and $\mathrm{S} 100 \beta^{+}$, and the precursor cells are $\mathrm{A} 2 \mathrm{~B} 5^{+}$. In contrast to purified astrocytes, purified APCs rapidly die in serum-free culture but can be saved by basic fibroblast growth factor (bFGF) and glial growth factor 2 (GGF2). Unlike oligodendrocyte precursor cells, APCs do not differentiate by default;
\end{abstract}

their differentiation into $\mathrm{GFAP}^{+}$cells is induced by ciliary neurotrophic factor (CNTF) or by leukemia inhibitory factor (LIF). Finally, the survival, proliferation, and differentiation of APCs were promoted by coculture with other embryonic optic nerve cell types but not with purified embryonic retinal ganglion cells, indicating that interactions with non-neuronal cells are likely to play an important role in controlling astrocyte generation in the developing optic nerve.

Key words: glial development; survival; proliferation; differentiation; glial growth factor (GGF); basic fibroblast growth factor (bFGF); ciliary neurotrophic factor (CNTF); leukemia inhibitory factor (LIF)
Although much recent progress has been made in understanding the development of oligodendrocytes and Schwann cells, much less is known about astrocyte development. There are two main types of astrocytes. Protoplasmic astrocytes are located in the gray matter and have end feet that contact synapses and blood vessels. Fibrous astrocytes are located in the white matter and have end feet that contact nodes of Ranvier and blood vessels (Peters et al., 1991). These two astrocyte types may have a different lineage. Some protoplasmic astrocytes are generated by multipotent subventricular zone progenitor cells (Levison and Goldman, 1993; Zerlin et al., 1995), whereas some fibrous astrocytes are generated by radial glia (Choi and Lapham, 1978; Schmechel and Rakic, 1979; Misson et al., 1988; Voigt, 1989; Goldman, 1996). The generation of astrocytes from multipotent neural stem cells in culture is induced by bone morphogenic factors (BMPs), ciliary neurotrophic factor (CNTF), and basic fibroblast growth factor (bFGF) (Gross et al., 1996; Johe et al., 1996; Bonni et al., 1997; Qian et al., 1997). There is some evidence that precursor cells committed to the astrocyte lineage exist (Fok-Seang and Miller, 1992; Davis and Temple, 1994; Qian et al., 1998), but it is not known how they are signaled to survive, proliferate, and differentiate.

The developing rat optic nerve has served as a simple model system for studies of cell-cell interactions that control glial development (Raff et al., 1983; Barres et al., 1992; Raff, 1989). The

Received Sept. 25, 1998; revised Nov. 6, 1998; accepted Nov. 10, 1998.

This work was supported by National Eye Institute Grant R29 EY10257 to B.A.B., National Multiple Sclerosis Society Grant RG2553 to B.A.B, and National Institutes of Health National Research Service Award 5F32NS10015 to H.M. We thank Cambridge Neuroscience for recombinant human GGF2, Jim Cohen for C5 neuroepithelial cell antibody, Ursula Drager for R5 anti-vimentin antibody, and Stephanie Sapperstein and Songli Wang for helpful comments on this manuscript.

Correspondence should be addressed to Dr. Ben A. Barres, Stanford University School of Medicine, Department of Neurobiology, Fairchild Science Building D235, Stanford, CA 94305-5125.

Copyright (C) 1999 Society for Neuroscience $\quad 0270-6474 / 99 / 191049-13 \$ 05.00 / 0$ optic nerve is part of central white matter and, in addition to the axons of retinal ganglion cells, contains the same glial cell types found in white matter throughout the CNS. Previous studies have provided evidence of two different glial lineages that develop within the nerve (Raff et al., 1984; Miller et al., 1985, 1989; Skoff, 1990). Type-1 astrocytes develop embryonically (Raff et al., 1984; Miller et al., 1985, 1989), whereas oligodendrocytes develop postnatally (Raff et al., 1983; Miller et al., 1985). The oligodendrocytes are generated by oligodendrocyte precursors cells (OPCs, also termed O-2As for oligodendrocyte type-2 astrocyte precursor cell) (Raff et al., 1983). It has been proposed that the type-1 astrocytes are generated by $\mathrm{RAN}-2^{+} \mathrm{GFAP}^{-}$cells because these cells are the major cell type in embryonic day 16 (E16) optic nerve and because type- 1 astrocytes are also $\mathrm{RAN}-2^{+}$(Raff et al., 1984). Type-2 astrocytes are a major astrocytic component in postnatal optic nerve cultures that are generated by OPCs cultured in the presence of fetal calf serum but are not presently thought to exist in vivo (Fulton et al., 1992).

Our understanding of the development of oligodendrocytes and Schwann cells has been assisted greatly by the identification, purification, and characterization in culture of Schwann cell precursor cells (Jessen and Mirsky, 1997) and oligodendrocyte precursor cells (Raff, 1989; Barres and Raff, 1994). Here we describe a method to purify astrocyte precursor cells (APCs) from the developing rat optic nerve. We purified APCs from embryonic rat optic nerve to $>95 \%$ purity by a sequential immunopanning procedure and characterized their antigenic and developmental properties in vitro. We found that the Pax 2 transcription factor is expressed specifically by all astrocyte lineage cells in the optic nerve throughout their development and not by oligodendrocytes or other cell types. APCs are $\mathrm{GFAP}^{-}, \mathrm{S} 100 \beta^{-}, \mathrm{A} 2 \mathrm{~B} 5^{+}$, and $\mathrm{Pax} 2^{+}$, whereas optic nerve astrocytes are $\mathrm{GFAP}^{+}, \mathrm{S} 100 \beta^{+}$, $\mathrm{A} 2 \mathrm{B5}^{-}$, and $\mathrm{Pax}_{2}^{+}$. Unlike astrocytes, purified APCs die in serum-free culture but can be stimulated to survive and divide by 
bFGF or by glial growth factor 2 (GGF2). In addition, purified APCs do not differentiate constitutively in serum-free culture but are induced to differentiate into $\mathrm{GFAP}^{+}$astrocytes by CNTF or by leukemia inhibitory factor (LIF). Finally, the survival, proliferation, and differentiation of APCs is promoted by signals from other optic nerve cell types.

\section{MATERIALS AND METHODS}

Detailed step-by-step protocols for all procedures are available on request (barres@stanford.edu).

Reagents. Recombinant human trophic factors were obtained from Peprotech (bFGF), Cambridge Neuroscience (GGF2), Regeneron (CNTF), and R \& D Systems (Minneapolis, MN; LIF). Monoclonal antibodies were obtained from Serotec (Indianapolis, IN; MRC-OX7 anti-Thy1.1 IgG antibody), American Type Culture Collection (Rockville, MD; A2B5), Jim Cohen (C5 neuroepithelial antibody), Developmental Hybridoma Bank (RAT401 anti-nestin antibody), Sigma (St. Louis, MO; anti-S100 $\beta$ antibody), Barbara Ranscht [Rmab antigalactocerebroside (anti-GC) antibody], Ursula Drager (R5 anti-vimentin antibody), and Boehringer Mannheim [Indianapolis, IN; anti-5-bromo-2'-deoxyuridine (BrdU) antibody]. Polyclonal antibodies were obtained from Babco (Richmond, CA; rabbit anti-Pax2 antiserum) and Dako (Carpinteria, CA; rabbit anti-GFAP antiserum).

Preparation of optic nerve cell suspension. Sprague Dawley rats (Simonson Labs) were used for all experiments. The date of plugging was E0. All embryos were examined to verify their ages, and obviously overage embryos were discarded.

Embryonic and postnatal optic nerves were dissected and enzymatically dissociated using papain as described previously (Barres et al., 1992). In brief, minced optic nerves were incubated at $37^{\circ} \mathrm{C}$ for $45 \mathrm{~min}$ [postnatal day $1(\mathrm{P} 1)$ ] or $30 \mathrm{~min}(\mathrm{E} 16-\mathrm{E} 19)$ in a papain solution (33 $\mathrm{U} / \mathrm{ml}$; Worthington, Freehold, NJ) in Dulbecco's PBS (DPBS) (Life Technologies, Gaithersburg, MD) containing L-cysteine $(0.4 \mathrm{mg} / \mathrm{ml})$ and DNase (125 units $/ \mathrm{ml})$. The tissues were then triturated sequentially in a solution containing ovomucoid $(2 \mathrm{mg} / \mathrm{ml})$, DNase $(125 \mathrm{units} / \mathrm{ml})$, and BSA $(1 \mathrm{mg} / \mathrm{ml})$ to yield a suspension of single cells. The cells were recovered by centrifugation at $1000 \times g$. On average, $\sim 13,000$ or 15,000 cells were obtained from each E17 or P1 optic nerve, respectively.

Purification of astrocytes and their precursor cells by sequential immunopanning. Optic nerve astrocytes from $\mathrm{P} 1$ rats were purified by sequential immunopanning as described previously (Barres et al., 1994). In brief, cell suspensions were incubated first on a panning dish coated with the MRC-OX7 anti-Thy1.1 antibody to deplete microglia and meningeal cells and then on a second dish coated with the A2B5 antibody to deplete OPCs. The remaining neuroepithelial cells were selected on the final dish coated with the C5 anti-neuroepithelial antibody (Miller et al., 1984). None of the A2B5 ${ }^{+}$cells depleted from the P1 (or older) suspensions had the phenotype of APCs that were only present embryonically (see Results). Astrocyte precursor cells were purified from E17 embryonic optic nerves by a similar procedure except that the A2B5 dish was omitted because almost no OPCs have migrated into the optic nerve by E17. (We did not purify APCs from E18 to E21 nerves, but this could be accomplished simply by using an O4 dish instead of the A2B5 dish so that OPCs but not APCs would be depleted.) The purified cells were recovered by trypsin digestion from the panning dish for further experiments. An average of $\sim 5000$ precursor cells or 4000 astrocytes was obtained from each E17 or P1 optic nerve, respectively. This represented a yield of $>90 \%$ of the precursor cells and astrocytes present in the cell suspensions that had survived the optic nerve dissociation procedure.

Culture of astrocytes and their precursor cells. Approximately 5000 purified astrocytes or their precursor cells were plated in $10 \mu \mathrm{l}$ of medium onto a 24 well culture dish (Falcon) or onto $1.2 \mathrm{~cm}$ glass coverslips (Marienfeld), both of which were precoated with poly-D-lysine ( $70 \mathrm{kDa} ; 10 \mu \mathrm{l} / \mathrm{ml}$; Sigma) and cultured for $10-15 \mathrm{~min}$. This preplating procedure is necessary to ensure the attachment of most of the cells to the culture dishes or coverslips. The cells were then cultured in $500 \mu \mathrm{l}$ of Bottenstein and Sato (B-S) serum-free medium [modified from Bottenstein and Sato (1979) as described previously (Lillien et al., 1990)], including the additives sodium pyruvate $(1 \mathrm{mM})$, glutamine $(1 \mathrm{mM})$, penicillin-streptomycin (100 units/ml), $N$-acetyl-cysteine $(60 \mathrm{mg} / \mathrm{ml})$, and hydrocortisone $(10 \mu \mathrm{M})$ and the appropriate trophic factors. In some cases, as indicated in the Results, chlorphenylthio-cAMP (CPT-cAMP; $125 \mu \mathrm{M})$ was added. Peptide trophic factors were used at the following levels: $10 \mathrm{ng} / \mathrm{ml}$ for bFGF, $50 \mathrm{ng} / \mathrm{ml}$ for GGF2, $10 \mathrm{ng} / \mathrm{ml}$ for CNTF, 10 $\mathrm{ng} / \mathrm{ml}$ for LIF, and $5 \mu \mathrm{g} / \mathrm{ml}$ for insulin. In some experiments, as indicated in the Results, APCs were cultured in B-S serum-free medium with insulin, CPT-cAMP, and bFGF for $1 \mathrm{hr}$ and were washed in B-S serum-free medium three times and then cultured in the appropriate media. The cells for BrdU assays were fed daily to supplement the factors. The initial percentage of GFAP-positive cells was assessed by immunostaining after $1 \mathrm{hr}$ of culture. The initial viability was usually assessed by the MTT assay 1-3 hr after plating (see below) and typically was over $90 \%$.

Coculture of APCs with mixed optic nerve cells or retinal ganglion cells. E17 mixed optic nerve cells were prepared by digesting optic nerves for $30 \mathrm{~min}$ in $0.125 \%$ trypsin solution, followed by trituration in DPBS with $10 \%$ FCS; 25,000-30,000 mixed cells were plated in each well of a 24 well culture plate with $500 \mu \mathrm{l}$ of B-S serum-free medium containing no peptide trophic factors except those indicated for survival assays or containing insulin and CPT-cAMP for proliferation and differentiation assays, as indicated. E19 RGCs were prepared according to the procedure described previously (Meyer-Franke et al., 1995). Approximately 40,000 retinal ganglion cells (RGCs) were plated in each well with $500 \mu \mathrm{l}$ of B-S serum-free medium supplemented with BDNF (10 $\mathrm{ng} / \mathrm{ml})$, B27 (1:50; Life Technologies), T3 (30 nM), and CPT-cAMP (125 $\mu \mathrm{M})$. Two days later, $5000 \mathrm{APCs}$ that had been preplated onto glass coverslips were added to the above cultures suspended over the optic nerve cells by glass chips, and another $500 \mu \mathrm{l}$ of the appropriate medium was added. Cells were fed every other day.

MTT survival assay. Approximately 5000 cells were plated per well into 24 well culture dishes (Falcon) and cultured for $3 \mathrm{~d}$, and the percentage of surviving cells was assessed by the MTT assay as described previously (Mosmann, 1983; Meyer-Franke et al., 1995). All values are given as the mean \pm SD of triplicates (unless otherwise mentioned) in one experiment. All experiments were repeated one or more times as indicated.

BrdU assay. To label cells in $\mathrm{S}$ phase in vivo, we injected $\mathrm{BrdU}(0.1$ $\mathrm{mg} / \mathrm{gm}$ of body weight in a DPBS solution; Boehringer Mannheim) intraperitoneally into the pregnant mother (for embryos) or perinatal rats. After $2 \mathrm{hr}$, the animals were killed, and the optic nerves were dissected, fixed, sectioned, and double immunostained by anti-BrdU and anti-Pax2 antibodies (see below).

To label cells in $\mathrm{S}$ phase in vitro, we added $\mathrm{BrdU}(10 \mu \mathrm{g} / \mathrm{ml})$, which is incorporated into replicating DNA, to the cultures for $2 \mathrm{hr}$, followed by fixation and staining with a BrdU antibody (see below).

Cryosection of optic nerves. Optic nerves were dissected and fixed in ice-cold $4 \%$ paraformaldehyde for $1 \mathrm{hr}$ and then infiltrated with $30 \%$ sucrose overnight at $4^{\circ} \mathrm{C}$. To label cells in $\mathrm{S}$ phase in vivo, we injected BrdU into pregnant or perinatal animals as described above. The animals were killed after $2 \mathrm{hr}$, and their optic nerves were fixed and cryoprotected as described above. The nerves were then sectioned longitudinally into 8 - $\mu$ m-thick cryosections that were collected on precoated slides (Sigma) and placed at room temperature for $30 \mathrm{~min}$ to air dry. The sections were stored at $-80^{\circ} \mathrm{C}$ until staining.

Immunofluorescence staining. The cryosections were baked at $50^{\circ} \mathrm{C}$ for $15 \mathrm{~min}$ to ensure the attachment of tissues to the slides. After fixation with $4 \%$ paraformaldehyde for $10 \mathrm{~min}$ at room temperature and a $30 \mathrm{~min}$ incubation in blocking buffer $(50 \%$ normal goat serum solution containing $150 \mathrm{~mm} \mathrm{NaCl}, 50 \mathrm{~mm}$ Tris, pH 7.4, 1\% BSA, $100 \mathrm{~mm}$ L-lysine, and $0.2 \%$ Triton $\mathrm{X}-100$ ) to block nonspecific binding, the cryosections of optic nerves were stained with the polyclonal Pax2 antiserum overnight, washed, and then incubated for $1 \mathrm{hr}$ in a fluorescein-coupled goat anti-rabbit IgG antibody (Jackson Lab). For the BrdU experiments, the optic nerve sections were incubated in $2 \mathrm{~N} \mathrm{HCl}$ for $10 \mathrm{~min}$ to denature the nuclear DNA, followed by an incubation in $0.1 \mathrm{M}$ sodium borate $\left(\mathrm{Na}_{2} \mathrm{~B}_{4} \mathrm{O}_{7}\right)$ for $5 \mathrm{~min}$. The sections were incubated in a blocking buffer containing $50 \%$ goat serum and $0.2 \%$ Triton $\mathrm{X}-100$ for $30 \mathrm{~min}$, double stained with the monoclonal anti-BrdU antibody (Boehringer Mannheim) and polyclonal Pax2 antiserum (Babco) overnight, and incubated with a fluorescein-coupled goat anti-rabbit $\mathrm{IgG}$ and a Texas Redconjugated goat anti-mouse IgG antibody (Jackson Lab) for $1 \mathrm{hr}$.

Cultured cells on coverslips were treated similarly except a shorter incubation time was used. The stained sections and cultures were mounted with Citiflour (Chemistry Lab, University of Kent, UK) and sealed with nail polish. A Nikon Microphot-FXA microscope was used to observe and photograph the fluorescence staining. 



Figure 1. The appearance of GFAP immunoreactivity in the developing rat optic nerve. Optic nerves from embryonic day $17(A)$ and postnatal day $1(B)$ rats were fixed, sectioned longitudinally, and stained with an antiGFAP antibody. GFAP expression was scarcely detected in E17 optic nerve $(A)$ but was found throughout the $P 1$ optic nerve $(B)$. Scale bar, $50 \mu \mathrm{m}$.

\section{RESULTS}

\section{Purification of optic nerve astrocytes and their precursor cells}

To determine when astrocyte generation begins in the optic nerve, we immunostained cryosections of optic nerves at various ages with an anti-GFAP antibody. There was little detectable signal in E17 optic nerve, except for occasional immunoreactivity near the pia (Fig. $1 A$ ). GFAP staining could be detected throughout the P1 (Fig. $1 B$ ) and adult optic nerve (data not shown). Because few astrocytes have developed at E17 and it is difficult to dissect out nerves before this age, we purified astrocyte precursor cells from E17 optic nerves.

Astrocyte lineage cells were purified from optic nerves of P1 and E17 rats by a sequential immunopanning procedure (see Materials and Methods). In brief, astrocytes were purified by sequential panning of a P1 optic nerve cell suspension on three Petri dishes coated with a monoclonal anti-Thy1.1 antibody to
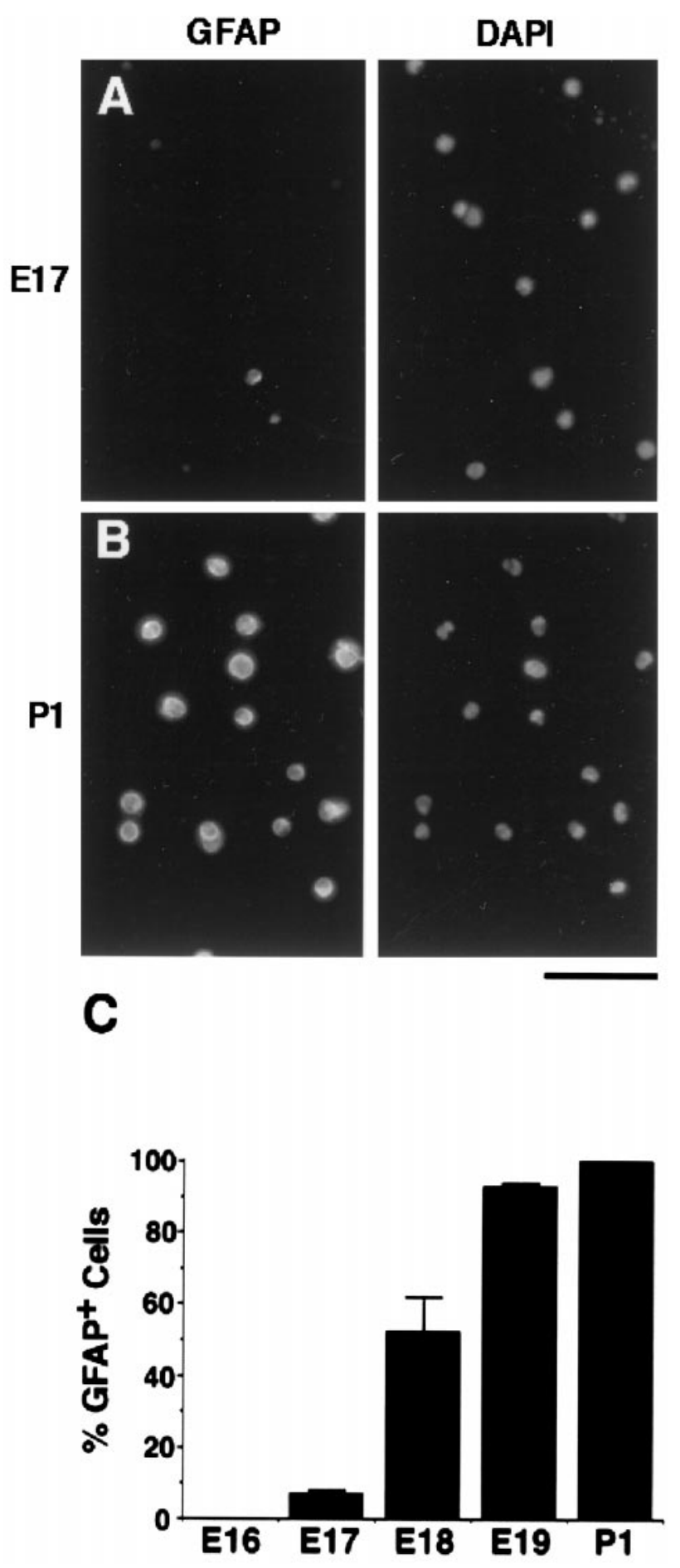

Figure 2. GFAP immunoreactivity in purified astrocytes and their precursor cells. $A, B$, Astrocyte lineage cells were purified from $E 17(A)$ and $P 1(B)$ rat optic nerves by immunopanning. Left, The cells were cultured for $1 \mathrm{hr}$ and then fixed and immunostained immediately with an antiGFAP antibody. Right, The total cells were viewed by counterstaining the nuclei with 4,6-diamidino-2-phenylindole $(D A P I)$. $C$, The percentage of $G F A P^{+}$cells was determined at various ages. The results represent means \pm SEM of two to five separate experiments, with triplicates in each experiment. Scale bar, $80 \mu \mathrm{m}$. 
Pax2

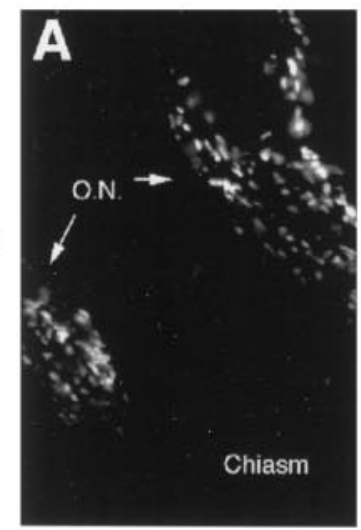

E17

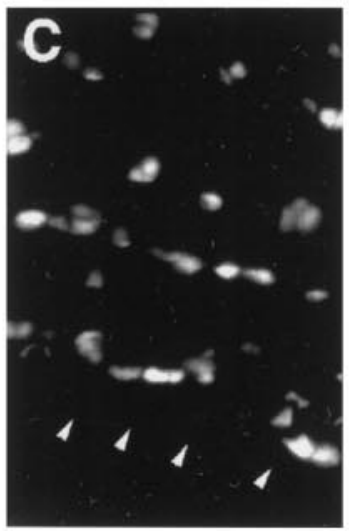

P8

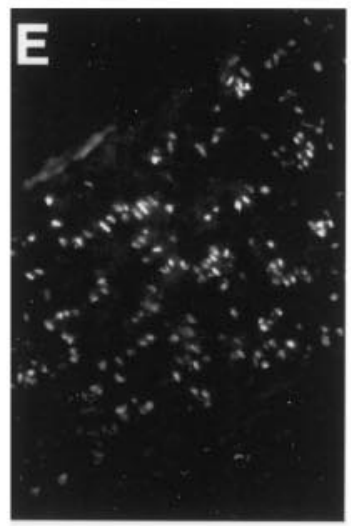

Adult



DAPI


deplete microglia, which adhere via their Fc receptors to the first antibody-coated dish on which they are incubated, and meningeal fibroblasts, with the monoclonal A2B5 antibody to deplete OPCs (Raff et al., 1983), and with a monoclonal C5 anti-neuroepithelial cell antibody to select astrocyte lineage cells (Miller et al., 1984). For purification of astrocyte precursor cells from E17 optic nerve, the Petri dish coated with the A2B5 antibody was omitted because there are no OPCs in the optic nerve at that age. Astrocytes were purified from P1 optic nerves to $>99 \%$ purity by this method, as assessed by staining with a GFAP antibody immediately after isolation (Fig. 2B,C). In contrast, there were virtually no GFAPpositive cells at E16 (Fig. $2 C$ ), and only $8 \%$ of the purified cells were $\mathrm{GFAP}^{+}$at E17 (Fig. $2 A, C$ ). The number of $\mathrm{GFAP}^{+}$cells increased rapidly to $42 \%$ at E18 and to $92 \%$ at E19 (Fig. $2 C$ ).

To determine whether the GFAP $^{-}$cells purified from E17 optic nerves with this procedure were astrocyte precursor cells, we cultured the purified cells to see whether they would differentiate into $\mathrm{GFAP}^{+}$cells. More than $95 \%$ of the purified cells became $\mathrm{GFAP}^{+}$in response to CNTF or LIF, indicating that these cells were astrocyte precursor cells (detailed results of differentiation studies are discussed below). Cells that did not bind to the $\mathrm{C} 5$ dish were collected and cultured in medium containing CNTF. Less than $1 \%$ of these cells became GFAP ${ }^{+}$ (data not shown), suggesting that we successfully purified the majority of astrocyte precursor cells from our optic nerve suspensions.

Because CNTF also induces A2B5 ${ }^{+} \mathrm{OPCs}$ to differentiate into $\mathrm{GFAP}^{+}$type-2 astrocytes (Hughes et al., 1988; Lillien et al., 1988), we next examined the possibility that we had purified OPCs instead of APCs. Three lines of evidence argue against this possibility. First, at E17, almost all OPCs in the optic nerve are found in the chiasm (Small et al., 1987), which is not included in our optic nerve dissection. Second, when the purified cells were cultured for $4 \mathrm{~d}$ in conditions that would allow OPCs to differentiate into oligodendrocytes (Raff et al., 1983; Barres et al., 1992), no cells could be stained by an anti-GC antibody, a specific marker of oligodendrocytes. Lastly, the $\mathrm{GFAP}^{+}$cells that differentiated from the purified APCs had the typical morphology of type-1 but not type-2 astrocytes (see below). Therefore, we conclude that the purified cells were astrocyte precursor cells and not OPCs.

\section{Antigenic characteristics of astrocytes and their precursor cells}

Pax 2 is a member of the pax protein transcription factor family that is characterized by a DNA-binding element called the paired box. Pax 2 has been shown to be expressed by glial-like cells in the embryonic mouse optic cup, stalk, and nerve (Nornes et al., 1990). This suggested the possibility that Pax 2 might be expressed specifically by astrocyte lineage cells. To examine this possibility, we immunostained optic nerve sections of different ages with a Pax2 antiserum (Fig. 3). At E17, most cells within the optic nerves were

\section{$\leftarrow$}

Figure 3. Pax2 immunoreactivity in the developing rat optic nerve Longitudinal sections of optic nerves from $E 17(A-D), P 8(E, F)$, and adult $(G, H)$ rat were stained with a $\operatorname{Pax} 2$ antiserum $(A, C, E, G)$ and with $D A P I(B, D, F, H)$. Nuclei of cells were labeled by Pax 2 along the length of the E17 optic nerve (O.N.) but not in the chiasm $(A, B)$. At higher magnification, only the cells within the parenchyma of the optic nerve were labeled; the pial cells were not labeled (arrowheads in $C, D$ ). The Pax2 labeling persisted in the optic nerve at $P 8(E, F)$ but became fainter in the adult optic nerve $(G, H)$. Scale bars: $A, B, E-H, 80 \mu \mathrm{m} ; C, D, 33 \mu \mathrm{m}$. 
DAPI
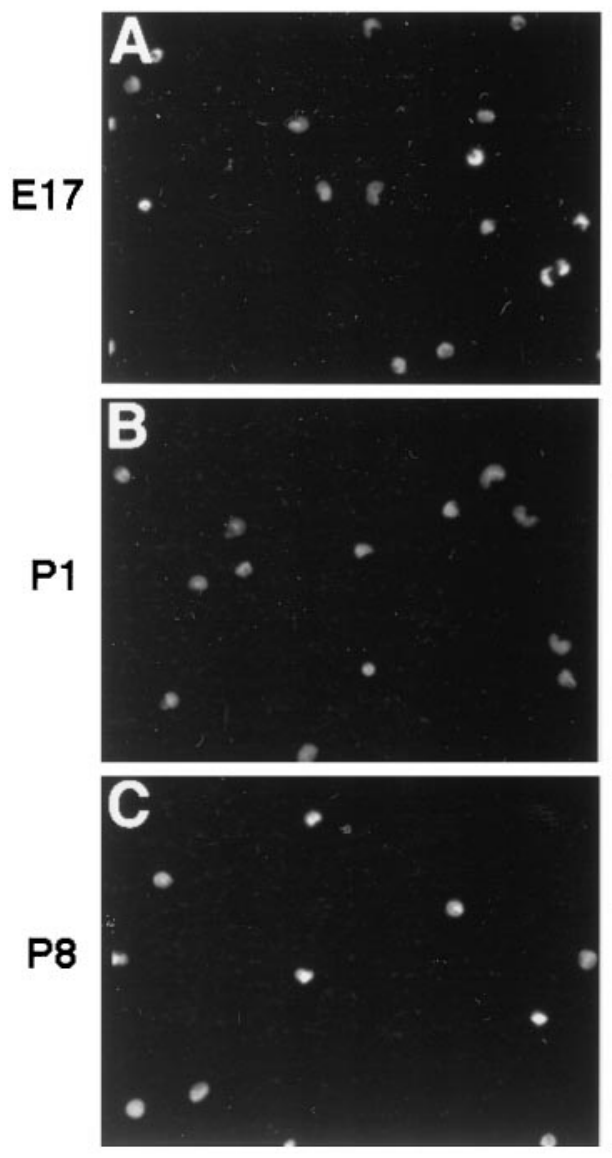

Pax2
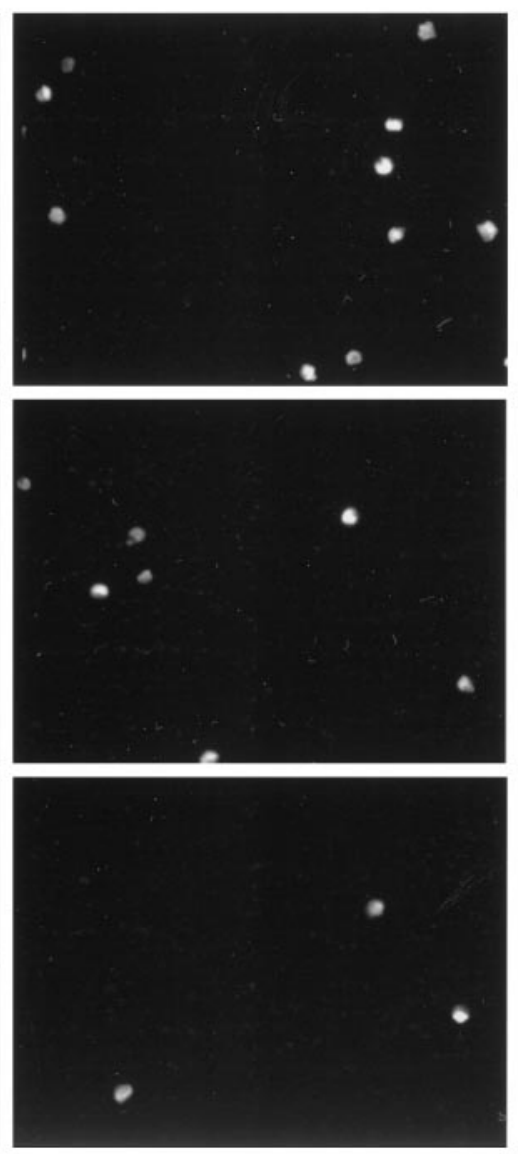

$S 100 \beta$
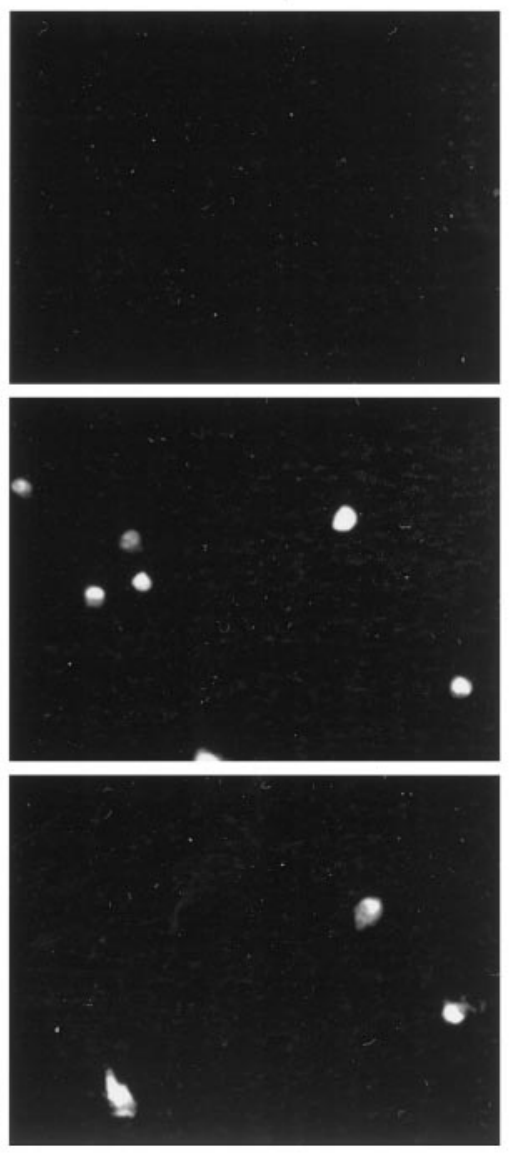

Figure 4. Pax2 immunoreactivity in optic nerve cell suspensions. Optic nerves were dissociated from $E 17(A), P 1(B)$, and $P 8(C)$ rats and then were double labeled with a Pax2 antiserum and an $S 100 \beta$ monoclonal antibody. The nuclei were counterstained by DAPI (left). Many nuclei at all three ages stained with the $\mathrm{Pax2}^{+}$antiserum (middle), and at $P 1$ and P8, the Pax2 immunoreactivity was colocalized in cells stained with $S 100 \beta$ antibody (right). Scale bar, $80 \mu \mathrm{m}$.

stained, whereas no cells in the optic chiasm were stained (Fig. $3 A, B)$. Because most OPCs are in the chiasm at E17, this finding suggested that it was unlikely that they express Pax2 (see below). Most of the cells stained by $\operatorname{Pax} 2$ were located in the parenchyma of the nerve rather than on the pial surface (Fig. $3 C, D$ ), suggesting that they are likely to be astrocyte lineage cells. Pax $2^{+}$cells in the optic nerves persisted in perinatal (Fig. $3 E, F)$ and adult (Fig. $3 G, H)$ optic nerves, although the expression level decreased in older nerves.

To determine further which cell type was Pax $2^{+}$, acutely isolated cells from optic nerves were stained using an anti-Pax2 antiserum (Fig. 4). At E17, $\sim 50 \%$ of the cells were Pax ${ }^{+}$(Fig. $4 A$ ). Over $95 \%$ of the purified APCs from E17 optic nerve $\left(\mathrm{C}^{+}\right.$ fraction) cells were $\mathrm{Pax} 2^{+}$, whereas only $\sim 2 \%$ of the other cells $\left(\mathrm{C} 5^{-}\right)$were stained. Nearly all of the S100 $\beta^{+}$astrocytes from P1 and P8 optic nerves were labeled by Pax2 (Fig. 4B,C), as were nearly all of the astrocytes purified from P1 optic nerves. No OPCs purified from P8 optic nerves were stained by Pax2. Thus, Pax2 is a specific marker for astrocyte lineage cells in the optic nerve and is present in astrocytes as well as in their precursor cells. Many $\mathrm{Pax} 2^{+} \mathrm{S} 100 \beta^{-}$APCs were present in embryonic optic nerve suspensions, but APCs with this phenotype were not present in $\mathrm{P} 1, \mathrm{P} 8$, or adult optic nerve suspensions.

We next examined the expression of previously reported astro-
Table 1. Comparison of the antigenic phenotypes of astrocyte precursor cells and perinatal astrocytes

\begin{tabular}{lll} 
& APCs & Astrocytes \\
\hline Pax2 & + & + \\
GFAP & - & + \\
S100 $\beta$ & - & + \\
A2B5 & + & - \\
C5 & + & + \\
RAN-2 & + & + \\
Vimentin & + & + \\
Nestin & \pm & \pm
\end{tabular}

Purified E17 APCs and P1 astrocytes were cultured for $1 \mathrm{hr}$ and immunostained by antibodies against each of the above markers. + indicates $>90 \%$ of the cells were positive, and - indicates $<10 \%$ of the cells were positive. Values in between these were considered \pm . Approximately $40 \%$ of the APCs and astrocytes were nestin ${ }^{+}$.

cyte markers. We immunostained purified populations of astrocyte precursor cells (E17) and of perinatal astrocytes (P1) with antibodies to these markers (Table 1). Both anti-GFAP and anti-S100 $\beta$ antibodies, which are specific markers of astrocytes, did not stain the APCs. The C5 monoclonal antibody, a marker of neuroepithelial cells, labeled both astrocytes and their precursors. Similarly, the RAN-2 monoclonal antibody (Bartlett et al., 1980) 
labeled both astrocytes and APCs as reported previously (Raff et al., 1984). Anti-vimentin antibody (Drager et al., 1984) labeled both precursor cells and astrocytes. Anti-nestin antibody, a marker of many neural stem cells (Frederiksen and McKay, 1988), labeled only some of the precursor cells as well as the perinatal astrocytes. The A2B5 monoclonal antibody, which in rats is a marker of OPCs as well as a recently identified multipotent glial precursor cell purified in the brain (Raff et al., 1983; Rao and Mayer-Proschel, 1997), lightly labeled the APCs but not the astrocytes. The A2B5 immunoreactivity on the APCs, although consistently present, was substantially weaker than that on OPCs. Thus, APCs have an antigenic phenotype that is $\mathrm{GFAP}^{-}$, $\mathrm{S} 100 \beta^{-}, \mathrm{A} 2 \mathrm{~B} 5^{+}$, and $\mathrm{Pax} 2^{+}$, whereas astrocytes are $\mathrm{GFAP}^{+}$, $\mathrm{S} 100 \beta^{+}, \mathrm{A} 2 \mathrm{~B} 5^{-}$, and $\mathrm{Pax} 2^{+}$.

\section{Effects of peptide trophic factors on the survival of astrocyte precursor cells}

To determine whether the purified P1 astrocytes or the E17 APCs can survive when cultured in B-S serum-free medium (Materials and Methods) lacking insulin and other peptide trophic factors, we performed an MTT survival assay after 24, 48, and $72 \mathrm{hr}$ of culture. The majority of P1 astrocytes survived for $3 \mathrm{~d}$ of culture, whereas most of the E17 APCs died after $48 \mathrm{hr}$ (Fig. 5A) with the typical shrunken cytoplasmic and nuclear morphology of apoptosis (Fig. $5 D$ ). Astrocytes did die, however, when cultured at clonal density (data not shown). These findings suggest that the astrocytes make their own survival signals, whereas the APCs require signals, presumably from neighboring cells, to survive.

We next assessed the effects of signals that have been reported to promote the survival of other neural cell types. To determine whether elevation of intracellular cAMP levels promotes survival, we cultured the precursor cells for $3 \mathrm{~d}$ in B-S serum-free medium containing forskolin. Survival was slightly, but significantly, improved (Fig. 5B). Because intracellular cAMP can be degraded by cyclic nucleotide phosphodiesterases, we also cultured the precursor cells in CPT-cAMP, a cell membranepermeable cAMP analog that is resistant to these phosphodiesterases. APC survival was improved further, to $\sim 40 \%$, but the majority of the cells still died (Fig. $5 B$ ). Surprisingly, when the precursor cells were cultured in medium containing $10 \%$ FCS, although the astrocytes survived as expected, almost all of the APCs died (Fig. 5B).

We next asked whether peptide trophic factors normally expressed in the developing optic nerve could promote survival of the astrocyte precursor cells. Insulin $(5 \mu \mathrm{g} / \mathrm{ml})$, used at a concentration sufficient to activate IGF-1 receptors, promotes survival of many other cell types including neurons and oligodendrocytes (Barres et al., 1992, 1993; Meyer-Franke et al., 1995). It did not promote, however, the survival of astrocyte precursor cells (Fig. $5 C$ ). GGF2 alone also showed little effect. bFGF alone weakly promoted survival (Fig. 5C) and together with insulin promoted the survival a little further (Fig. 5C). When CPT-cAMP was added, however, bFGF and GGF2 promoted the survival of $\sim 95$ and $65 \%$ of cells, respectively (Fig. $5 C$ ). CPT-cAMP appeared to act synergistically with GGF2 and additively with bFGF. Other peptide trophic factors tested, including platelet-derived growth factor (PDGF-AA and -BB), transforming growth factor $\alpha$ (TGF $\alpha$ ), members of the TGF $\beta$ family (BMP2,4,7), sonic hedgehog (SHH), neurotrophin 3 (NT3), NT4, vascular endothelial growth factor (VEGF), LIF, and CNTF, did not promote the survival of APCs, even when tested together with CPT-cAMP.
The morphology of the E17 APCs cultured under high-survival conditions (bFGF, insulin, and CPT-cAMP together) was similar to that in cultures of $\mathrm{P} 1$ astrocytes, which nearly entirely consist of type-1 astrocytes (Fig. 5D). These findings show that bFGF, GGF2, and cAMP elevation collaborate to promote the survival of APCs.

\section{Effects of bFGF and GGF2 on proliferation of astrocyte precursor cells}

To determine what signals induce APCs to proliferate in the serum-free medium, we next measured their DNA synthesis rates when cultured for $4 \mathrm{~d}$ in B-S serum-free medium containing various peptide trophic factors. We added BrdU $(10 \mu \mathrm{M})$ to the culture medium for $2 \mathrm{hr}$ and determined the percentage of cells that incorporated BrdU into their DNA (see Materials and Methods). When APCs were cultured in B-S serum-free medium without any factors, the majority of the cells died. Because these cells were cultured on glass coverslips, on which APCs survive less well compared with survival on tissue culture plastic, the survival rate was $<10 \%$. To enhance survival, we cultured APCs with bFGF for only $1 \mathrm{hr}$ and then switched to medium lacking peptide factors. We found that such a transient exposure to bFGF promoted survival but little proliferation. For instance, in this case $>90 \%$ of APCs survived for at least $4 \mathrm{~d}$, but $<4 \%$ of them were $\mathrm{BrdU}^{+}$(Fig. 6A). When APCs were cultured for $4 \mathrm{~d}$ with GGF2 or bFGF in the presence of CPT-cAMP, DNA synthesis increased significantly with 8 and $17 \%$ of the APCs incorporating BrdU, respectively (Fig. $6 A$; a $17 \%$ uptake suggests the APCs are dividing very rapidly, at least once per day). The elimination of CPT-cAMP from the medium only slightly decreased these percentages (data not shown), and the combination of GGF2 and bFGF together did not increase proliferation further. None of the other peptide trophic factors tested, including SHH, PDGF-AA, PDGF-BB, TGF $\alpha$, members of the TGF $\beta$ family (BMP2,4,7), NT3, NT4, VEGF, and CNTF, stimulated proliferation of the APCs. These results show that APCs have a low spontaneous division rate and need to be signaled to divide more rapidly.

To compare directly the in vitro proliferation rate with that in vivo, we determined the proliferation rates of APCs and astrocytes in the optic nerve at various ages using a BrdU assay (see Materials and Methods). We injected BrdU into pregnant (for E16-E18) and perinatal (for P1, P5, and P8) animals and after 2 hr killed the animals. The proliferation rates were obtained by double immunostaining cryosections of the optic nerves from the BrdU-injected animals or their embryos with the anti-Pax2 antiserum and the anti-BrdU antibody. Figure $6 B$ summarizes the percentage of $\mathrm{Pax}_{2}{ }^{+}$astrocyte lineage cells that incorporated BrdU in optic nerves at various ages. At E16, over $40 \%$ of APCs were $\mathrm{BrdU}^{+}$(Fig. 6B), but this percentage dropped quickly during the next $2 \mathrm{~d}$ concurrently with the rapid onset of astrocyte differentiation during that period of time (Fig. 2). A low level of proliferation persisted after birth, because 5 and $2 \%$ of the astrocytes were still $\mathrm{BrdU}^{+}$at $\mathrm{P} 1$ and $\mathrm{P} 8$, respectively. Thus, although astrocytes and APCs divide in vivo, APCs divide much more rapidly.

\section{Effects of CNTF and LIF on the differentiation of astrocyte precursor cells}

To determine whether the precursor cells would differentiate into $\mathrm{GFAP}^{+}$astrocytes by default, we cultured the APCs in B-S serum-free medium for $4 \mathrm{~d}$ and stained with an anti-GFAP antibody. At the time of plating, only $\sim 8 \%$ of the purified E17 
A.

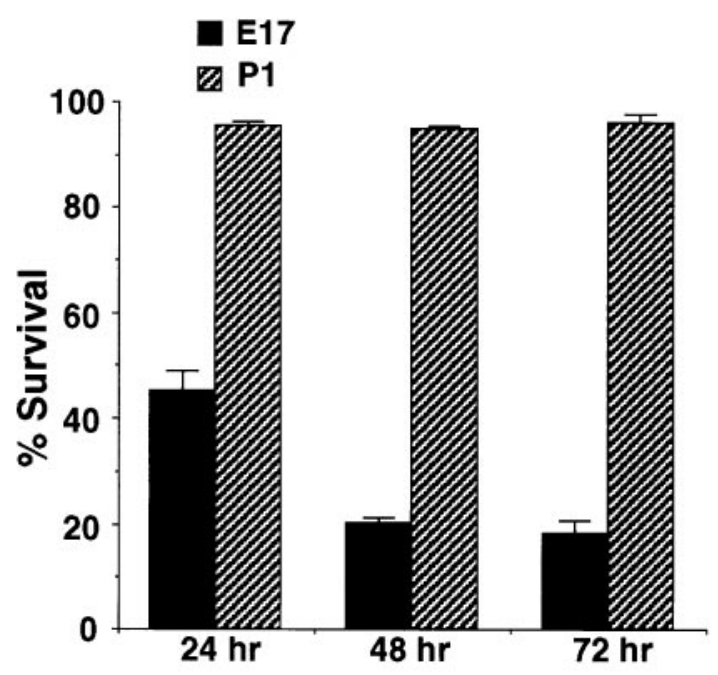

C.

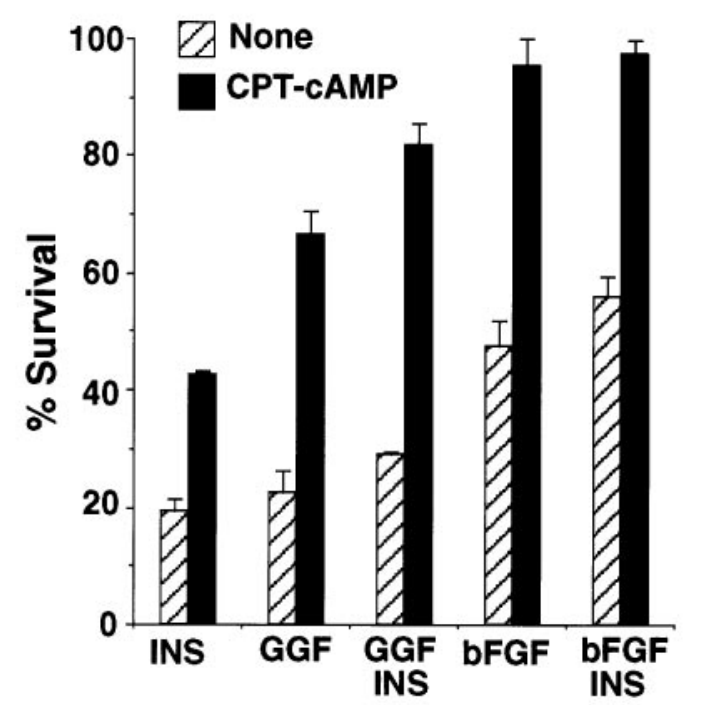

B.

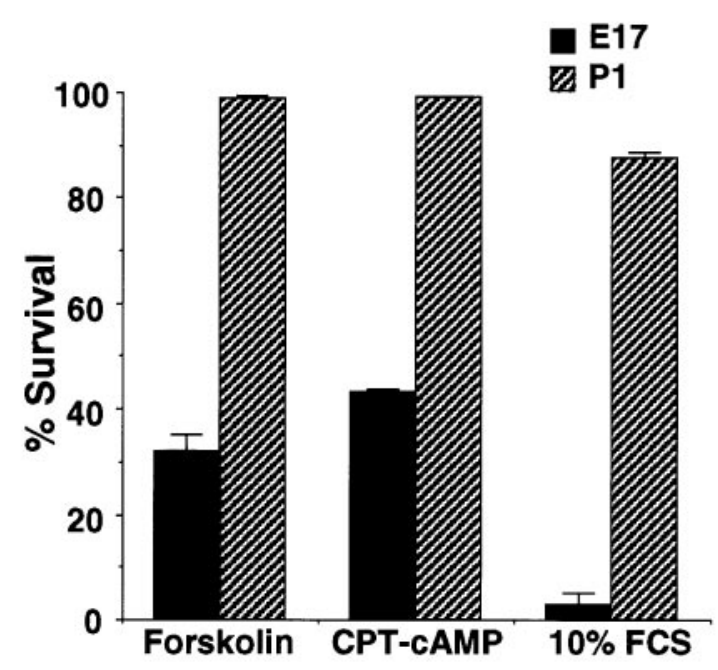

D.
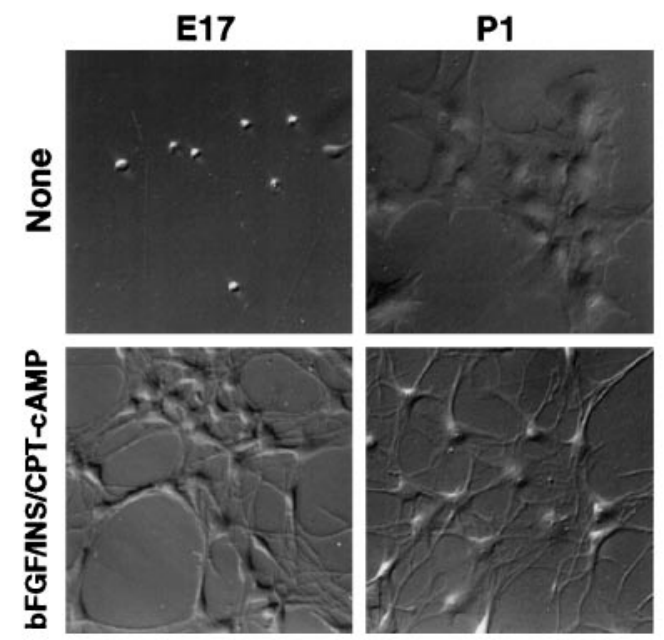

Figure 5. Survival of purified astrocyte precursor cells in culture. $A$, Purified astrocytes $(P 1)$ and their precursor cells $(E 17)$ were cultured in serum-free, insulin-free modified B-S medium in 24 well culture plates for the times indicated. B, Purified APCs were cultured for $3 \mathrm{~d}$ in the serum-free B-S medium containing forskolin or $C P T-c A M P$ or in DMEM containing $10 \%$ FCS. C, Purified APCs were cultured in serum-free B-S medium containing insulin $(I N S), C P T-c A M P$, or peptide trophic factors as indicated. Survival was determined by the MTT assay after $72 \mathrm{hr}$, unless otherwise indicated. The results represent the means \pm SD of three wells in a single experiment and were repeated in at least three separate experiments. $D$, Phase-contrast micrographs of $P 1$ astrocytes and $E 17$ precursor cells in culture are shown. The purified cells were cultured in medium lacking peptide trophic factors (None) or with basic FGF, insulin, and CPT-cAMP (bFGF/INS/CPT-cAMP). Scale bar, $80 \mu \mathrm{m}$.

APCs were $\mathrm{GFAP}^{+}$(see above). After $4 \mathrm{~d}$ in culture, the majority of the cells had died, but most of the surviving cells were still GFAP $^{-}$. Similarly, when we enhanced the survival of the APCs by culturing them for $1 \mathrm{hr}$ in bFGF and CPT-cAMP and then replaced the medium with $\mathrm{B}-\mathrm{S}$ serum-free medium lacking peptide trophic factors for $4 \mathrm{~d}$, only $\sim 20 \%$ of cells were GFAP ${ }^{+}$ (Figs. 7, 8A). Addition of insulin, CPT-cAMP, bFGF, GGF2, or all of these together did not significantly increase the amount of astrocyte differentiation further (data not shown).
We next investigated whether peptide trophic signals normally present in the nerve could promote the differentiation of APCs into astrocytes. A number of the factors tested, including BMP2,4,7, PDGF-AA, PDGF-BB, NT3, NT4, TGF $\alpha$, TGF $\beta 1$, and $\mathrm{SHH}$, did not significantly promote astrocyte differentiation. When CNTF or LIF was added to the B-S serum-free medium, however, most cells died, but nearly all of the surviving cells became $\mathrm{GFAP}^{+}$. When the cells were cultured initially for $1 \mathrm{hr}$ with bFGF, insulin, and CPT-cAMP to improve their survival to 


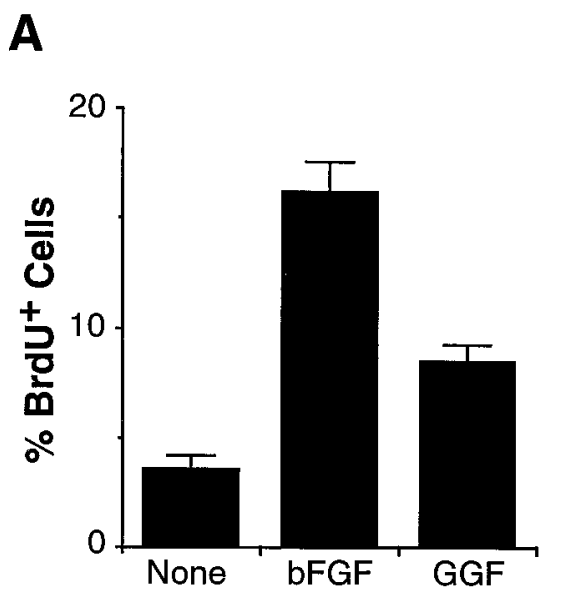

B

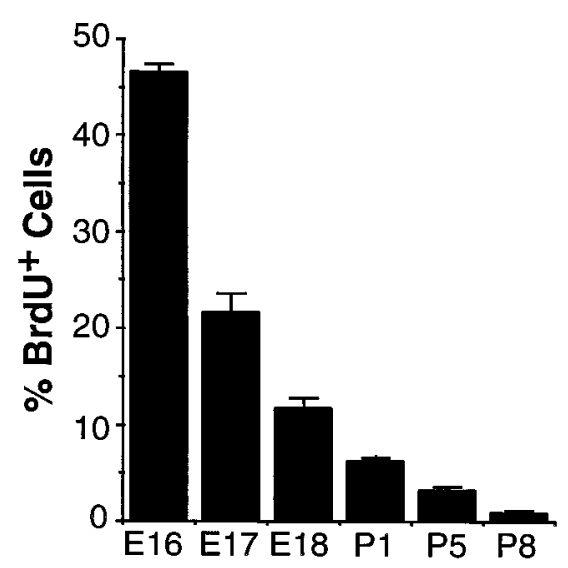

Figure 6. Proliferation of astrocyte precursor cells. A, Purified APCs were cultured in $b F G F$ for $1 \mathrm{hr}$, followed by washing and culture in serum-free B-S medium containing CPT-cAMP and the indicated peptide factors. After $4 \mathrm{~d}$, the cells were incubated with $B r d U$ for $2 \mathrm{hr}$ and stained by an anti-BrdU antibody. The percentage of $\mathrm{BrdU}^{+} \mathrm{APCs}$ over total APCs was counted. The results represent means $\pm \mathrm{SD}$ of three wells of a single experiment and were confirmed by at least three separate experiments. $B$, Proliferation of astrocyte lineage cells in vivo is shown. Two hours after an intraperitoneal injection of $B r d U$, optic nerves of various ages were sectioned and stained by a monoclonal anti-BrdU antibody and a polyclonal anti-Pax2 antiserum. At each age, the percentage of $\mathrm{Pax} 2^{+}$cells that was also $\mathrm{BrdU}^{+}$was determined. The results are means \pm SEM of six sections from three different animals in each age group.

almost $100 \%$ and subsequently were treated for $4 \mathrm{~d}$ with CNTF (Figs. 7, 8C,D) or LIF (Figs. 7, 8E,F), $>95 \%$ of the cells differentiated into GFAP $^{+}$astrocytes. This effect of CNTF and LIF to increase the percentage of astrocytes in these cultures is instructive rather than selective, because in this experiment nearly all of the cells survived. The morphology of the differentiated cells was very similar to that of $\mathrm{GFAP}^{+}$astrocytes purified from $\mathrm{P} 1$ optic nerves (Fig. $8 G, H$ ). Taken together, these findings show that APCs do not differentiate into GFAP ${ }^{+}$astrocytes at an appreciable rate unless signaled to do so by extrinsic signals such as CNTF or LIF.

CNTF only needed to be added to the cultures for $1 \mathrm{hr}$ to induce the majority of the APCs to differentiate (data not

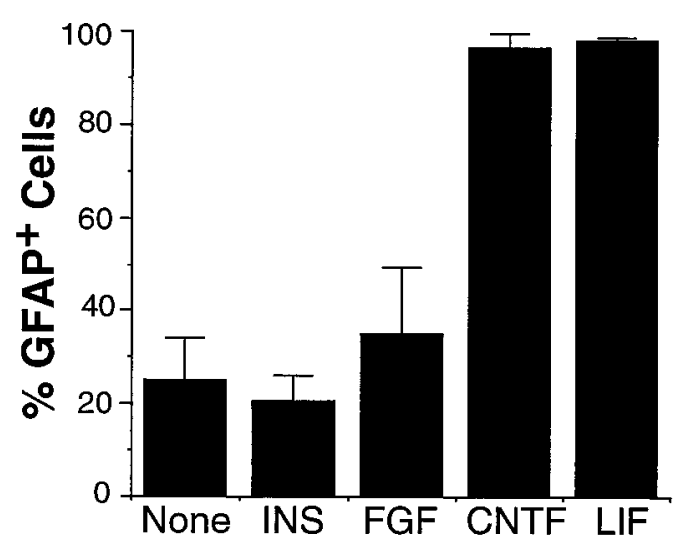

Figure 7. Effect of peptide trophic factors on the differentiation of astrocyte precursor cells. Purified astrocyte precursor cells were cultured in B-S serum-free medium containing bFGF, CPT-cAMP, and insulin for $1 \mathrm{hr}$, subsequently were washed and cultured in medium containing the indicated factors for $4 \mathrm{~d}$, and then were immunostained with an antiGFAP antibody. The data represent means $\pm \mathrm{SD}$ of six samples of a single experiment and were confirmed by three separate experiments.

shown). The differentiation-inducing effect of CNTF was not reversible because when the APCs were treated with CNTF to induce their differentiation into astrocytes and then switched to serum-free medium containing bFGF but lacking CNTF and cultured for several days, GFAP staining was still present (data not shown).

\section{Effects of mixed optic nerve cells on survival, proliferation, and differentiation of astrocyte precursor cells}

The present findings show that the purified APCs do not survive, proliferate, or differentiate unless induced to do so by specific peptide signals known to be produced within the developing optic nerves. To determine what cell types are controlling APC development, we cultured the purified E17 APCs above a conditioning layer of mixed E17 embryonic optic nerve cells (see Materials and Methods). Approximately $50 \%$ of the APCs survived for $3 \mathrm{~d}$ (Fig. $9 A$ ), compared with only $15 \%$ of cells cultured in the absence of optic nerve cells. To examine whether optic nerve cells also promoted the proliferation or differentiation of the APCs, we repeated this experiment but added insulin and CPT-cAMP to the culture medium to enhance the survival of the APCs further. After $4 \mathrm{~d}, \sim 5 \%$ of the APCs were $\mathrm{BrdU}^{+}$in cocultures, whereas only $1 \%$ of the APCs were positive in control cocultures lacking optic nerve cells (Fig. 9B). Nearly identical values were obtained when BrdU incorporation was measured after $2 \mathrm{~d}$ of culture. Finally, APCs were stained by an anti-GFAP antibody after $4 \mathrm{~d}$ of culture alone or in coculture with the mixed optic nerve cells. Over $80 \%$ of the APCs were GFAP $^{+}$in coculture, compared with $20 \%$ in control cultures (Fig. 9C). Thus, astrocyte differentiation occurs in vitro with approximately the same time course that would have occurred if the APCs had remained in vivo. Taken together, these findings show that soluble signals from mixed optic nerve cells strongly promote the survival and differentiation of APCs and weakly promote their proliferation.

RGCs have been reported recently to drive the proliferation of postnatal astrocytes in the optic nerve, raising the question of whether they also drive APC proliferation in the embryonic optic nerve. We thus next cultured the purified E17 APCs for $3 \mathrm{~d}$ in direct contact with, rather than over a conditioning layer of, 


\section{GFAP}
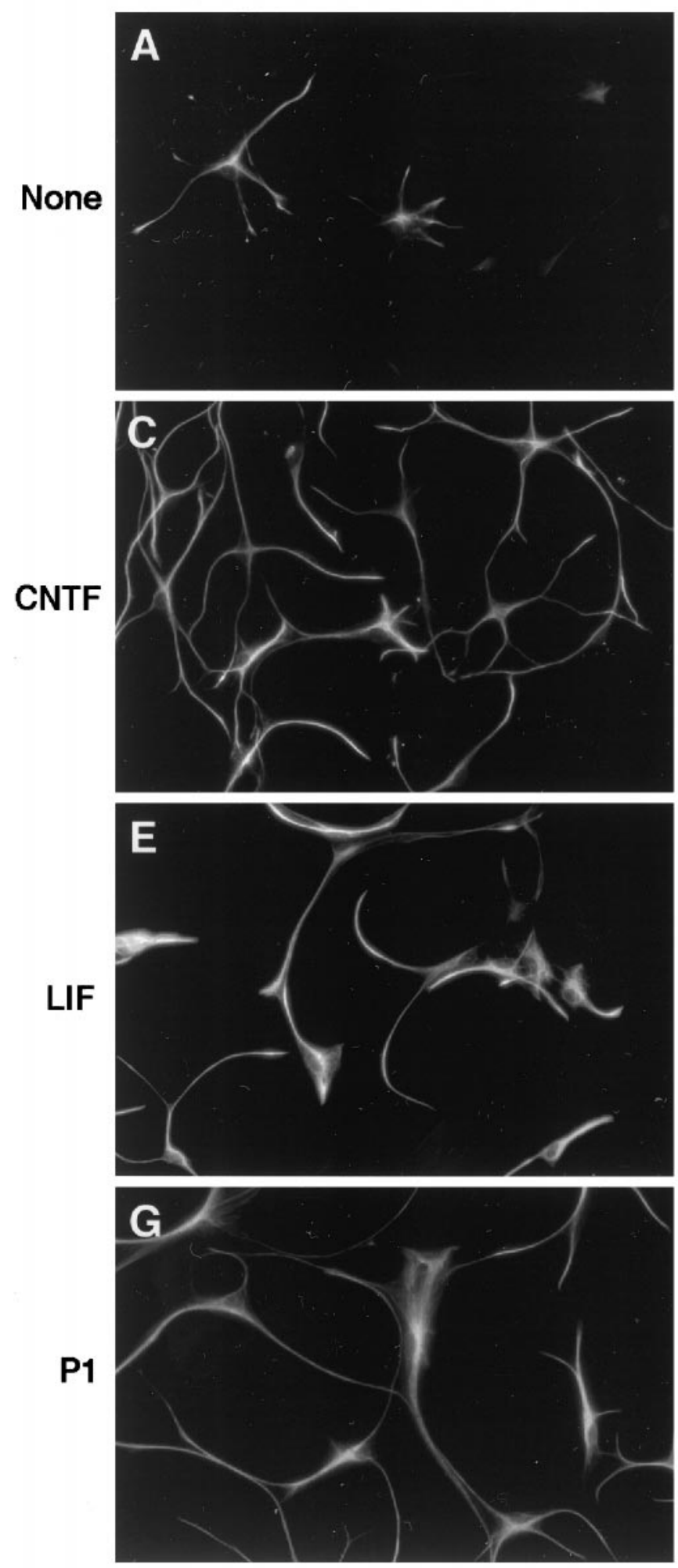

DAPI


$\mathrm{He}$

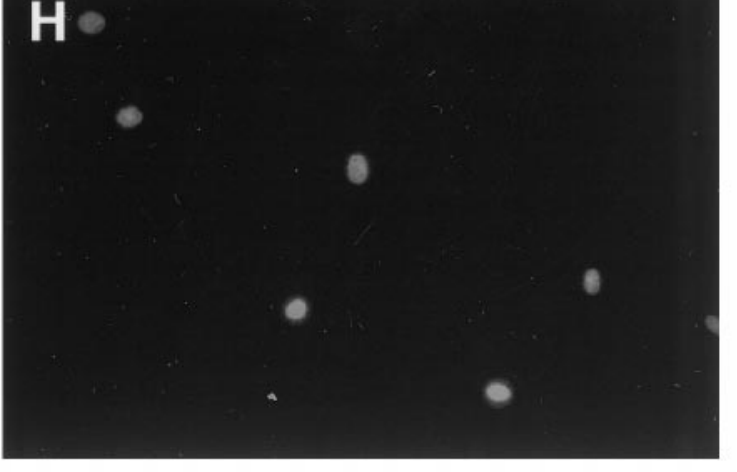

Figure 8. Effects of $C N T F$ and $L I F$ on the differentiation of astrocyte precursor cells. $A-F$, Astrocyte precursor cells were cultured in B-S serum-free medium containing bFGF, CPT-cAMP, and insulin for $1 \mathrm{hr}$ to promote their survival and then were changed to a medium lacking $(A, B)$ or containing $C N T F(C, D)$ or $L I F(E, F)$. After 4 d, the cells were fixed and stained with an anti-GFAP antibody $(A, C, E)$. Nuclei were visualized by $D A P I$ staining $(B, D, F)$. Almost all of the cells treated with $C N T F$ or $L I F$ were stained by $G F A P$ antibody. $G, H$, The morphology of these cells looked quite similar to that of astrocytes purified from $P 1$ rat optic nerves. Scale bar, $80 \mu \mathrm{m}$. 
A

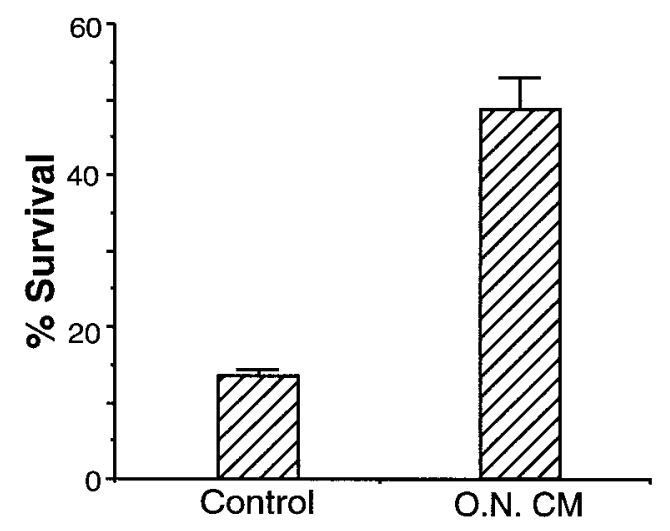

B
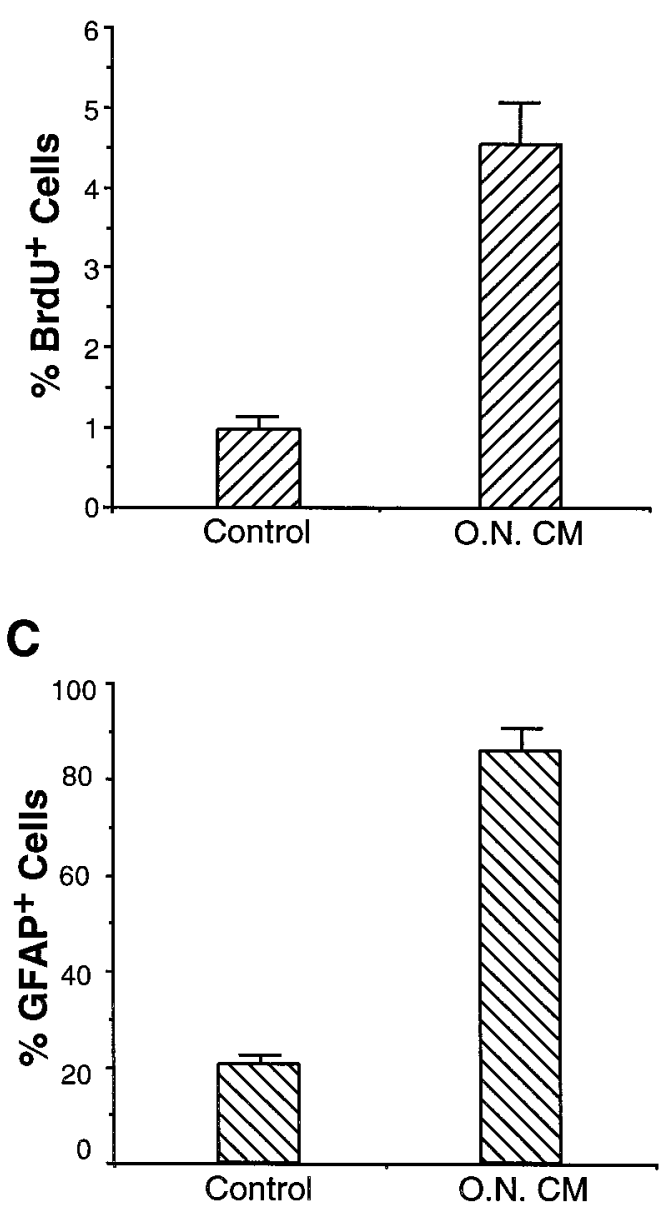

Figure 9. Effect of mixed optic nerve cells on survival, proliferation, and differentiation of APCs in culture. APCs were cocultured above a conditioning layer of E17 mixed optic nerve cells that had been allowed to condition the medium for $2 \mathrm{~d}$ before addition of the APCs (the cocultures are labeled $O . N$. CM). APCs cultured on glass coverslips without optic nerve cells were used as controls. $A$, After $4 \mathrm{~d}$ of culture, survival of APCs was determined morphologically. $B$, Proliferation of APCs was studied by a $B r d U$ assay, as described in the text. $C$, Differentiation was studied by GFAP immunostaining. The results represent means $\pm \mathrm{SD}$ of three samples and were confirmed by at least one additional experiment. purified E17 RGCs in the presence of BDNF, insulin, and CPTcAMP to help promote RGC survival (Meyer-Franke et al., 1995). We allowed direct contact because of the possibility that bFGF or neuregulin isoforms could be on the axonal membrane rather than secreted into the medium. Neither the survival, proliferation, nor differentiation of the APCs was significantly promoted compared with that of purified APCs cultured in the same culture medium in the absence of RGCs, even when APCs were transiently cultured with bFGF to promote their survival. GGF2 together with optic nerve cells did not stimulate proliferation of APCs over optic nerve cells or GGF2 alone (data not shown).

\section{DISCUSSION}

\section{Astrocyte precursor cells can be antigenically identified, purified, and cultured}

The purification and culture of progenitor cells have provided a powerful approach for understanding how their survival, proliferation, and differentiation are controlled. In brain development, just as in the hematopoietic system, initially multipotent stem cells, capable of generating many types of neurons and glia, give rise to progressively more restricted precursor cells. For instance, precursors from embryonic and postnatal brain that are restricted to generating just neurons, astrocytes, and oligodendrocytes or just oligodendrocytes have been identified (Raff et al., 1983; Levison and Goldman, 1993; Davis and Temple, 1994; Rao and Mayer-Proschel, 1997; Qian et al., 1998; Shen et al., 1998). Whether or not cells committed to the production of astrocytes exist has not been clear.

In the present study, we have identified a glial precursor cell present in large numbers in embryonic rat optic nerve that appears to be committed to giving rise to astrocytes and not to oligodendrocytes; whether it could give rise to neurons if placed in environments other than the optic nerve is not yet clear. A strong case can be made that the APCs we purified must be the main precursor cells for optic nerve astrocytes. First, the astrocyte precursors and astrocytes share several antigens including the Pax 2 transcription factor. Second, virtually all of the neuroepithelial cells isolated from E17 optic nerve are Pax2 ${ }^{+}$cells that have the capacity to give rise to astrocytes in vitro. Third, the numbers of APCs at E17 appear appropriate to generate rapidly the large number of astrocytes present in E19 nerves. We typically isolated $\sim 5000$ APCs per E17 nerve, and by E19 there are $\sim 10,000$ astrocytes per nerve, which is reasonably consistent with our finding that the APCs at E17 were dividing at a rate of approximately once per day and that some glial apoptosis is occurring within the nerve at this stage (B. A. Barres, unpublished observations). Finally, because nearly all of the neuroepithelial cells in the E17 nerve are APCs, there is no alternative candidate cell present in sufficient number to give rise to so many astrocytes by E19.

The APCs that we identified, purified, and cultured are thus the precursor cells for fibrous astrocytes within the optic nerve, as originally suggested by Martin Raff et al. (1984). Whether these cells are similar to other types of astrocyte precursors within the brain or have the capability to generate other types of astrocytes will be addressed in future studies. In any case, the ability to purify and culture these cells should allow further elucidation of the intrinsic and extrinsic signaling mechanisms that normally control the development of these cells within the optic nerve. 


\section{Pax2 is a specific astrocyte lineage marker in optic nerve}

The present studies show that in the developing optic nerve, the paired-box transcription factor Pax2 is a specific marker of astrocyte lineage cells, with nuclear immunoreactivity found in all astrocytes and their precursors but not in oligodendrocyte lineage cells, microglial cells, endothelial cells, or meningeal cells. The APCs could be distinguished from astrocytes by the additional presence of other antigens in the astrocytes including GFAP and $\mathrm{S} 100 \beta$. Interestingly, as has been reported for all other glial precursor cells identified to date in the rat brain, the APCs stained on their surfaces with the A2B5 antibody.

During normal development, optic nerve axons interact tightly with the optic stalk cells, which in turn differentiate into glial cells (Horsburgh and Sefton, 1986). Pax2 is required for patterning in the optic stalk because transgenic mice lacking Pax2 have defective closure of the optic fissure, defective establishment of axonal pathways along the optic stalk, few optic nerve glia, and agenesis of the optic chiasm (Torres et al., 1996; Macdonald et al., 1997). The lack of optic nerve glia in the Pax2-deficient mice, together with the presence of Pax2 in nearly all astrocytes and APCs, suggests that Pax 2 plays a crucial role in determining the APC fate.

Is Pax 2 a marker of other types of astrocytes, such as fibrous astrocytes in other white matter pathways in the brain? Pax2 was not expressed by astrocytes in the optic chiasm (this paper), and in preliminary experiments it was also not expressed by astrocytes in the corpus callosum (our unpublished observations). Thus although optic nerve astrocytes have many similarities to fibrous astrocytes in other brain regions, they have clear antigenic differences such as the expression of Pax2 as well as the RAN-2 antigen, which is also not present on astrocytes in the optic chiasm or corpus callosum (Barres, unpublished observations). This is not surprising because regional astrocyte heterogeneity has been documented frequently before.

\section{APCs must be signaled by other cell types to survive and proliferate}

We found that purified APCs quickly died in serum-free culture but could be saved and induced to proliferate by bFGF, by GGF2, or by medium conditioned by other embryonic optic nerve cell types. In contrast, purified optic nerve astrocytes, when cultured at similar density, survived and proliferated in the absence of added signals, although at low density they died and did not proliferate. These findings suggest that although to some extent astrocytes are able to produce signals that help to promote their own survival and proliferation, APCs cannot, raising the question of which cell types normally signal the APCs to survive and divide.

Developing retinal ganglion cells produce both bFGF and neuregulins including GGF2 (de Iongh and McAvoy, 1992; Shi et al., 1998), and RGC axons strongly stimulate the development of APCs in the developing optic nerve (Silver and Robb, 1979; Horsburgh and Sefton, 1986), raising the question of whether RGCs may normally help to stimulate the survival and proliferation of APCs. A similar role for axon-derived neuregulins, which stimulate Schwann cell survival, proliferation, and differentiation in vitro, has recently been demonstrated for Schwann cell development in vivo (Riethmacher et al., 1997), and it has been shown that optic nerve axons drive the proliferation of astrocytes in the postnatal optic nerve (Burne and Raff, 1997). They showed that astrocyte proliferation in postnatal nerves nearly ceased after optic nerve transection and that in culture studies retinal ganglion cells stimulated astrocyte division. This effect was mimicked by addition of bFGF but not GGF2. To date our data do not provide any direct support for the possibility that embryonic RGCs drive the development of APCs because we failed to detect a promotion of APC survival, proliferation, or differentiation when they were cultured together with embryonic RGCs. It is possible, however, that the embryonic RGCs in culture behave differently than they do in vivo.

In contrast, survival and proliferation of the APCs were significantly stimulated by embryonic optic nerve cells. The main cell types in the embryonic optic nerve, other than the APCs themselves, include pial cells and vascular endothelial cells. Because astrocytes make extensive contacts with both pial cells and blood vessels (Suarez and Raff, 1989; Peters et al., 1991), it would make some sense for either or both cell types to help promote APC survival or proliferation (see below).

\section{Differentiation of APCs into astrocytes does not occur by default but requires extrinsic signals}

Committed oligodendrocyte precursor cells generate oligodendrocytes in culture by default without the need for any specific inducing signals when their mitogens are withdrawn (Raff et al., 1983; Barres et al., 1994). In contrast, we found that optic nerve astrocyte precursor cells do not differentiate in culture, even when they are not dividing, unless they are induced to differentiate by a specific signal. The two signals that we have identified to date that induce their differentiation are CNTF and LIF. Both cytokines have been suggested previously to induce multipotent neural stem cells in culture to give rise to astrocytes (Johe et al., 1996; Bonni et al., 1997), although, because purified populations of stem cells were not studied, the possibility that CNTF and LIF acted on a more restricted precursor cell could not be completely excluded. The present studies show clearly that the action of CNTF and LIF in inducing astrocytes is instructive and not selective because these two signals do not promote the survival of either the astrocyte precursor cells or the astrocytes.

Do CNTF or LIF normally induce astrocyte differentiation in the developing optic nerve? CNTF is almost certainly not involved because it is expressed in the optic nerve only postnatally, whereas most of the APCs differentiate into astrocytes embryonically (Stockli et al., 1991). In addition, in contrast to LIF, CNTF lacks a secretory signal sequence, and there is not yet any convincing evidence that it is normally secreted. LIF, however, is an excellent candidate. When the LIF receptor is mutated, there is a marked decrease in both GFAP expression and astrocyte generation in culture and in vivo (Ware et al., 1995; Koblar et al., 1998), and in preliminary experiments we have found that LIF mRNA is expressed by non-neural cells in the embryonic optic nerve (our unpublished observations).

Finally, our findings raise the question of which cell type signals the APCs to differentiate into astrocytes in the optic nerve. The differentiation of the APCs into astrocytes occurs primarily on E18 and E19, long after axons have traversed the optic nerve, suggesting that axons probably do not play a crucial role. Our studies show that embryonic optic nerve cell types other than APCs, which primarily consist of pial cells and vascular endothelial cells, secrete an activity that is sufficient to induce most of the APCs to differentiate into astrocytes. Because astrocytes contact both pial cells and endothelial cells, either cell type could be the source of the inducing activity. Endothelial cells are a particularly plausible candidate for several reasons. First, endothelial cells in the optic nerve and brain are closely surrounded by 
astrocyte processes (Peters et al., 1991). Second, there is a good temporal correlation in the developing brain between the contact of blood vessels by glial precursor cells and the expression of GFAP by these cells (Zerlin and Goldman, 1997). Third, the differentiation of astrocytes in the optic nerve is both temporally correlated with its vascularization in late embryonic development and spatially correlated as astrocytes develop in an outside-toinside sequence correlating with the outside-to-inside vascularization of nervous tissue. Taken together, these findings suggest that non-neural cell types within the optic nerve, either endothelial cells or pial cells, play an important role in controlling astrocyte generation during optic nerve development. Because it is now possible to purify and culture the astrocyte precursor cells, it should be straightforward in future studies to test this hypothesis directly.

\section{REFERENCES}

Barres BA, Raff MC (1994) Control of oligodendrocyte number in the developing rat optic nerve. Neuron 12:935-942.

Barres BA, Hart IK, Coles HS, Burne JF, Voyvodic JT, Richardson WD, Raff MC (1992) Cell death and control of cell survival in the oligodendrocyte lineage. Cell 70:31-46.

Barres BA, Schmid R, Sendnter M, Raff MC (1993) Multiple extracellular signals are required for long-term oligodendrocyte survival. Development 118:283-295.

Barres BA, Raff MC, Gaese F, Bartke I, Dechant G, Barde YA (1994) A crucial role for neurotrophin-3 in oligodendrocyte development. Nature 367:371-375.

Bartlett PF, Noble MD, Pruss RM, Raff MC, Rattray S, Williams CA (1980) Rat neural antigen-2 (RAN-2): a cell surface antigen on astrocytes, ependymal cells, Muller cells and lepto-meninges defined by a monoclonal antibody. Brain Res 204:339-351.

Bonni A, Sun Y, Nadal-Vicens M, Bhatt A, Frank DA, Rozovsky I, Stahl N, Yancopoulos GD, Greenberg ME (1997) Regulation of gliogenesis in the central nervous system by the JAK-STAT signaling pathway. Science 278:477-483.

Bottenstein JE, Sato GH (1979) Growth of a rat neuroblastoma cell line in serum-free supplemented medium. Proc Natl Acad Sci USA 76:514517.

Burne JF, Raff MC (1997) Retinal ganglion cell axons drive the proliferation of astrocytes in the developing rodent optic nerve. Neuron 18:223-230.

Choi BH, Lapham LW (1978) Radial glia in the human fetal cerebrum: a combined Golgi, immunofluorescent and electron microscopic study. Brain Res 148:295-311.

Davis AA, Temple S (1994) A self renewing multipotential stem cell in the embryonic rat cerebral cortex. Nature 372:263-266.

de Iongh R, McAvoy JW (1992) Distribution of acidic and basic fibroblast growth factors in the fetal rat eye. Growth Factors 6:159-177.

Drager UC, Edwards DL, Barnstable CJ (1984) Antibodies against filamentous components in discrete cell types of the mouse retina. J Neurosci 4:2025-2042.

Fok-Seang J, Miller RH (1992) Astrocyte precursors in neonatal rat spinal cord cultures. J Neurosci 12:2751-2764.

Frederiksen K, McKay RD (1988) Proliferation and differentiation of rat neuroepithelial precursor cells in vivo. J Neurosci 8:1144-1151.

Fulton BP, Burne JF, Raff MC (1992) Visualization of O-2A progenitor cells in the developing and adult rat optic nerve by quisqualatestimulated cobalt uptake. J Neurosci 12:4816-4833.

Goldman JE (1996) Developmental origins of astrocytes. In: Glial cell development (Jessen KR, Richardson WD, eds), pp 31. Oxford: BIOS Scientific.

Gross RE, Mehler MF, Mabie PC, Zang Z, Santschi L, Kessler JA (1996) Bone morphogenetic proteins promote astroglial lineage commitment by mammalian subventricular zone progenitor cells. Neuron 17:595-606.

Horsburgh GM, Sefton AJ (1986) The early development of the optic nerve of the rat. J Comp Neurol 243:547-560.

Hughes SM, Lillien LE, Raff MC, Rohrer H, Sendtner M (1988) Ciliary neurotrophic factor induces type-2 astrocyte differentiation in culture. Nature 335:70-73.
Jessen KR, Mirsky R (1997) Embryonic Schwann cell development: the biology of Schwann cell precursors and early Schwann cells. J Anat 191:501-505.

Johe KK, Hazel TG, Muller T, Dugich-Djordjevic MM, McKay RD (1996) Single factors direct the differentiation of stem cells from the fetal and adult central nervous system. Genes Dev 10:3129-3140.

Koblar SA, Turnley AM, Classon BJ, Reid KL, Ware CB, Cheema SS, Murphy M, Bartlett PF (1998) Neural precursor differentiation into astrocytes requires signaling through the leukemia inhibitory factor receptor. Proc Natl Acad Sci USA 95:3178-3181.

Levison SW, Goldman JE (1993) Both oligodendrocytes and astrocytes develop from progenitors in the subventricular zone of postnatal rat forebrain. Neuron 10:201-212.

Lillien LE, Sendtner M, Rohrer H, Hughes SM, Raff MC (1988) Type-2 astrocyte development in rat brain cultures is initiated by a CNTF-like protein produced by type-1 astrocytes. Neuron 1:485-494.

Lillien LE, Sendtner M, Raff MC (1990) Extracellular matrix-associated molecules collaborate with ciliary neurotrophic factor to induce type-2 astrocyte development. J Cell Biol 111:635-644.

Macdonald R, Scholes J, Strahle U, Brennan C, Holder N, Brand M, Wilson SW (1997) The Pax protein Noi is required for commissural axon pathway formation in the rostral forebrain. Development 124:2397-2408.

Meyer-Franke A, Kaplan MR, Pfrieger FW, Barres BA (1995) Characterization of the signaling interactions that promote the survival and growth of developing retinal ganglion cells in culture. Neuron 15:805-819.

Miller RH, Williams BP, Cohen J, Raff MC (1984) A4: an antigenic marker of neural tube-derived cells. J Neurocytol 13:329-338.

Miller RH, David S, Patel R, Abney ER, Raff MC (1985) A quantitative immunohistochemical study of macroglial cell development in the rat optic nerve: in vivo evidence for two distinct glial lineages. Dev Biol 111:35-41.

Miller RH, ffrench-Constant C, Raff MC (1989) The macroglial cells of the rat optic nerve. Annu Rev Neurosci 12:517-534.

Misson JP, Edwards MA, Yamamoto M, Caviness Jr VS (1988) Identification of radial glial cells within the developing murine central nervous system: studies based upon a new immunohistochemical marker. Dev Brain Res 44:95-108.

Mosmann T (1983) Rapid colorimetric assay for cellular growth and survival. J Immunol Methods 65:55-63.

Nornes HO, Dressler GR, Knapik EW, Deutsch U, Gruss P (1990) Spatially and temporally restricted expression of Pax2 during murine neurogenesis. Development 109:797-809.

Peters A, Palay SL, Webster HF (1991) The fine structure of the nervous system. New York: Oxford UP.

Qian X, Davis AA, Goderie SK, Temple S (1997) FGF2 concentration regulates the generation of neurons and glia from multipotent cortical stem cells. Neuron 18:81-93.

Qian X, Goderie SK, Shen Q, Stern JH, Temple S (1998) Intrinsic programs of patterned cell lineages in isolated vertebrate CNS ventricular zone cells. Development 125:3143-3152.

Raff MC (1989) Glial cell diversification in the rat optic nerve. Science 243:1450-1455.

Raff MC, Miller RH, Noble M (1983) A glial progenitor cell that develops in vitro into an astrocyte or an oligodendrocyte depending on culture medium. Nature 303:390-396.

Raff MC, Abney ER, Miller RH (1984) Two glial cell lineages diverge prenatally in rat optic nerve. Dev Biol 106:53-60.

Rao MS, Mayer-Proschel M (1997) Glial-restricted precursors are derived from multipotent neuroepithelial stem cells. Dev Biol 188:48-63.

Riethmacher D, Sonnenberg-Reithmacher E, Brinkmann V, Yamaai T, Lewin GR, Birchmeier C (1997) Severe neuropathies in mice with targetted mutations in the ErbB3 receptor. Nature 389:725-730.

Schmechel DE, Rakic P (1979) A Golgi study of radial glial cells in developing monkey telencephalon: morphogenesis and transformation into astrocytes. Anat Embryol (Berl) 156:115-152.

Shen Q, Qian X, Capela A, Temple S (1998) Stem cells in the embryonic cerebral cortex: their role in histogenesis and patterning. J Neurobiol 36:162-174.

Shi J, Marinovich A, Barres BA (1998) Purification and characterization of adult oligodendrocyte precursor cells from the rat optic nerve. J Neurosci 18:4627-4636. 
Silver J, Robb R (1979) Studies on the development of the eye cup and optic nerve in normal mice and in mutants with congenital optic nerve aplasia. Dev Biol 68:175-190.

Skoff RP (1990) Gliogenesis in rat optic nerve: astrocytes are generated in a single wave before oligodendrocytes. Dev Biol 139:149-168.

Small RK, Riddle P, Noble M (1987) Evidence for migration of oligodendrocyte-type-2 astrocyte progenitor cells into the developing rat optic nerve. Nature 328:155-157.

Stockli KA, Lillien LE, Nahernoe M, Breitfeld G, Hughes RA, Raff MC, Thoenen H, Sendtner M (1991) Regional distribution, developmental changes, and cellular localization of CNTF mRNA and protein in the rat brain. J Cell Biol 115:447-459.

Suarez I, Raff MC (1989) Subpial and perivascular astrocytes associated with nodes of Ranvier in the rat optic nerve. J Neurocytol 18:577-582.

Torres M, Gomez-Pardo E, Gruss P (1996) Pax2 contributes to inner ear patterning and optic nerve trajectory. Development 122:3381-3391.
Voigt T (1989) Development of glial cells in the cerebral wall of ferrets: direct tracing of their transformation from radial glia into astrocytes. J Comp Neurol 289:74-88.

Ware CB, Horowitz MC, Renshaw BR, Hunt JS, Liggitt D, Koblar SA, Gliniak BC, McKenna HJ, Papayannopoulou T, Thoma B, Cheng L, Donovan PJ, Preschon JJ, Bartlett PF, Willis CR, Wright BD, Carpenter MK, Davison BL, Gearing DP (1995) Targeted disruption of the low-affinity leukemia inhibitory factor receptor gene causes placental, skeletal, neural and metabolic defects and results in perinatal death. Development 121:1283-1299.

Zerlin M, Goldman JE (1997) Interactions between glial progenitors and blood vessels during early postnatal corticogenesis: blood vessel contact represents an early stage of astrocyte differentiation. J Comp Neurol 387:537-546.

Zerlin M, Levison SW, Goldman JE (1995) Early patterns of migration, morphogenesis, and intermediate filament expression of subventricular zone cells in the postnatal rat forebrain. J Neurosci 15:7238-7249. 